\title{
Landfill leachate as nutritional source in castor bean cultivation under semi-arid conditions
}

\author{
Jerônimo Andrade Filho' ${ }^{1}$ Nildo da S. Dias ${ }^{2}$, Rafael O. Batista ${ }^{3}$, \\ José A. Santos Júnior ${ }^{4}$, Anne G. D. Santos ${ }^{5}$ \& Ana L. F. Lima ${ }^{6}$ \\ ${ }^{1}$ Instituto Federal de Ciência e Tecnologia do Rio Grande do Norte. Mossoró, RN. E-mail: jeronimoandrade@hotmail.com - ORCID: 0000-0002-0664-1752 \\ ${ }^{2}$ Universidade Federal Rural do Semi-Árido/Departamento de Ciências Agronômicas e Florestais. Mossoró, RN. E-mail: nildo@ufersa.edu.br - ORCID; \\ 0000-0002-1276-5444 \\ ${ }^{3}$ Universidade Federal Rural do Semi-Árido/Departamento de Engenharia e Ciências Ambientais. Mossoró, RN. E-mail: rafaelbatista@ufersa.edu.br \\ (Corresponding author) - ORCID: 0000-0002-3083-6808 \\ ${ }^{4}$ Universidade Federal Rural de Pernambuco/Departamento de Engenharia Agrícola. Recife, PE. E-mail: eng.amiltonjr@hotmail.com- ORCID: 0000-0002-1656-7103 \\ ${ }^{5}$ Universidade do Estado do Rio Grande do Norte/Departamento de Química. Mossoró, RN. E-mail: gabriella.uern@gmail.com - ORCID: 0000-0001-7434-1105 \\ ${ }^{6}$ Universidade de São Paulo/Escola Superior de Agricultura Luiz de Queiroz, Piracicaba, SP, E-mail: ferreira.analuizal@gmail.com - ORCID: 0000-0002-2888-1263
}

\section{Key words:}

waste disposal

irrigation

oilseed crops

\begin{abstract}
A B S T R A C T
The relevance of using technology for the rational destination of waste from a wide range of human activities is imminently paramount. In this context, between September 2014 and January 2015, in Mossoró, RN, Brazil (5 11' 31" S; 37²0’40” W), the present work was conducted to evaluate strategies for the utilization of landfill leachate as source of water and nutrients in agriculture. For this, castor bean plants (Ricinus communis L.), cv. BRS Energia, cultivated in eutrophic Red Yellow Argisol, were subjected to irrigation depth application strategies, namely: initial application of leachate corresponding to $20,40,60$ and $80 \%$ of the irrigation depth and subsequent application of the remaining water depth percentage using public-supply water, plus one control, which consisted of irrigation with publicsupply water + mineral fertilization recommended for the crop. These treatments were set in randomized blocks, with four replicates, totalizing twenty experimental plots. Mineral fertilization resulted in more expressive biometric responses at the beginning of the cycle; however, at the end, treatments based on leachate led to results, including of production, compatible with the control, especially plants irrigated with the $20 \%$ irrigation depth.
\end{abstract}

Palavras-chave:

destinação de resíduo líquido irrigação

oleaginosas

\section{Percolado de aterro sanitário como fonte nutricional no cultivo da mamoneira em condições semiáridas}

\begin{abstract}
R E S U M O
A pertinência do uso da tecnologia para destinação racional dos resíduos oriundos das mais diversas atividades humanas é iminentemente precípua. Neste contexto, entre setembro de 2014 e janeiro de 2015, em Mossoró, RN (5 11' 31' Sul - 37²0’40” Oeste), desenvolveu-se o presente trabalho com o objetivo de avaliar o uso de estratégias com vistas ao aproveitamento do percolado de aterro sanitário como fonte de água e nutrientes na agricultura. Para tal, submeteram-se plantas de mamona (Ricinus communis L.) cv. BRS Energia, cultivadas em Argissolo vermelho-amarelo Eutrófico, a estratégias de aplicação da lâmina de irrigação, a saber, a aplicação inicial do percolado de aterro sanitário correspondente a 20, 40, 60 e $80 \%$ da lâmina e a posterior aplicação do percentual restante da lâmina de irrigação em água de abastecimento, mais uma testemunha que consistiu na irrigação com água de abastecimento + adubação mineral recomendada para a cultura. Estes tratamentos foram alocados em blocos ao acaso, com quatro repetições, totalizando vinte parcelas experimentais. Verificou-se que a fertilização mineral resultou em respostas biométricas mais expressivas no início do ciclo, no entanto, ao final, os tratamentos à base de percolado proporcionaram resultados, inclusive de produção, compatíveis com a testemunha, com destaque para as plantas irrigadas com $20 \%$ da lâmina.
\end{abstract}




\section{INTRODUCTION}

Given its high polluting potential (Avramidou et al., 2013), the destination of landfill leachate (Vera-Romero et al., 2015) must not be considered separately from its also high nutritional content (Nunes Júnior et al., 2016) especially for agriculture, provided that adequate soil conservation practices are performed (Coelho et al., 2015) and provided that it is applied in crops allowed by the legislation, such as oilseed crops.

The use of other effluents in the cultivation of oilseed crops (Ricinus communis L.) has already been properly studied (Simões et al., 2013), as well as the effect of water stress and even the use of brackish and saline water (Brito et al., 2015), besides various other alternative sources of water in the production of oilseed crops (Ribeiro et al., 2012). Nonetheless, studies focused on developing strategies for the agricultural use of landfill leachate are still incipient and scarce.

Castor bean is a plant from the Euphorbiaceae family with C3 photosynthetic metabolism, rustic, heliophyte and well adapted to the peculiarities of the Brazilian semi-arid region (Severino et al., 2004). In the case of the cultivar BRS Energia, the mean yield is $1,800 \mathrm{~kg} \mathrm{ha}^{-1}$ under rainfed conditions, in regions where rainfall is at least $500 \mathrm{~mm}$. Regarding the nutritional requirement, Crusciol et al. (2012) observed that the hybrid Savana extracted 31 to $155 \mathrm{~kg}$ of N, 3 to $17 \mathrm{~kg}$ of $\mathrm{P}$, 13 to $71 \mathrm{~kg}$ of K, 12 to $56 \mathrm{~kg}$ of $\mathrm{Ca}, 4$ to $28 \mathrm{~kg}$ of $\mathrm{Mg}$ and 7 to $29.5 \mathrm{~kg}$ of S per hectare in off season and season, respectively.

Thus, the present study aimed to evaluate strategies of landfill leachate utilization as water and nutritional source in the irrigation of castor bean plants, cv. BRS Energia, grown in the semi-arid region of Rio Grande do Norte, based on its growth and production.

\section{Material AND Methods}

The study was carried out under field conditions from September 2014 to January 2015, in the Water Reuse Experimental Area (UERA) of the Federal Rural University of the Semi-Arid Region (UFERSA), in Mossoró, RN, Brazil (5 11'31" S; 37 20' 40" W; 18 m).

Treatments consisted of irrigation depth application strategies, namely: initial application of landfill leachate corresponding to $20,40,60$ and $80 \%$ of the total water depth necessary to meet crop water needs and subsequent application of the remaining water depth percentage using public-supply water, plus one control, which consisted of irrigation with public-supply water $\left(\mathrm{EC}=0.62 \mathrm{dS} \mathrm{m}^{-1}\right)+$ mineral fertilization recommended for the crop. These treatments were randomly distributed in blocks, with four replicates, totaling twenty experimental plots.

Variations in meteorological parameters (Table 1) did not either result in any phytosanitary problem or cause influence on the imposed treatments.

The experimental plots were set with $4.0 \times 6.0 \mathrm{~m}\left(24 \mathrm{~m}^{2}\right)$ and the soil in the area was classified as eutrophic Red Yellow Argisol. Soil samples were collected and characterized for physical and chemical properties (EMBRAPA, 1997), showing the following results: $0.79,0.07$ and $0.14 \mathrm{~kg} \mathrm{~kg}^{-1}$ of sand, silt and clay, respectively, and bulk density of $2.52 \mathrm{~g} \mathrm{~cm}^{-3}$ in the first $30 \mathrm{~cm}$. For the chemical parameters, in $20 \mathrm{~cm}$ depth, the results were: $\mathrm{pH}=6.53 ; \mathrm{EC}=0.49 \mathrm{dS} \mathrm{m}{ }^{-1} ; 12.96$ and $0.77 \mathrm{~g} \mathrm{~kg}^{-1}$ of $\mathrm{OM}$ and $\mathrm{N}$, respectively. The contents of $\mathrm{P}, \mathrm{K}$ and Na were 14.2, 99.5 and $9.4 \mathrm{mg} \mathrm{dm}^{-3}$, while $\mathrm{Ca}, \mathrm{Mg}, \mathrm{Al}, \mathrm{H}+\mathrm{Al}, \mathrm{SB}, \mathrm{T}$ and CEC were equal to 2.9, 0.9, 0.0, 0.99, 4.1, 4.1 and $5.09 \mathrm{cmol} \mathrm{dm}_{c}^{-3}$ and $\mathrm{V}, \mathrm{m}$ and ESP values were 81,0 and $0.8 \%$, respectively.

The castor bean (Ricinus communis L.) cultivar BRS Energia was sown in holes spaced by $0.60 \mathrm{~m}$ between plants and 1.0 $\mathrm{m}$ between rows, using three seeds per hole. At 20 days after sowing (DAS), thinning was performed to leave only one plant per hole.

The leachate used came from the stabilization pond of the Municipal Landfill of Mossoró-RN and was characterized (Table 2) according to the Standard Methods for the Examination of Water and Wastewater (Rice et al., 2012).

Table 1. Means of climatic parameters monitored along the experimental period

\begin{tabular}{lrrrrr}
\hline \multicolumn{1}{c}{ Climatic parameters* } & \multicolumn{1}{c}{ Sep-Oct } & Oct-Nov & Nov-Dec & Dec-Jan & Jan-Feb \\
Wind speed $\left(\mathrm{km} \mathrm{h}^{-1}\right)$ & 2.9 & 3.3 & 3.2 & 3.2 & 2.3 \\
Radiation $\left(\mathrm{W} \mathrm{m}^{-2}\right)$ & 4.8 & 4.9 & 4.6 & 4.2 & 4.2 \\
Relative air humidity $(\%)$ & 56.5 & 57.2 & 61.3 & 61.0 & 67.7 \\
Mean air temperature $\left({ }^{\circ} \mathrm{C}\right)$ & 28.3 & 28.2 & 28.0 & 28.2 & 27.8 \\
Rainfall $(\mathrm{mm})$ & 0.1 & 0.0 & 0.0 & 0.0 & 0.2 \\
ETo $\left(\mathrm{mm} \mathrm{d}^{-1}\right)$ & 6.1 & 6.2 & 6.1 & 6.2 & 6.2 \\
\hline
\end{tabular}

*Values obtained between the days 15 and 14 , respectively, of the referred months

Table 2. Physical and biochemical characterization of the landfill leachate

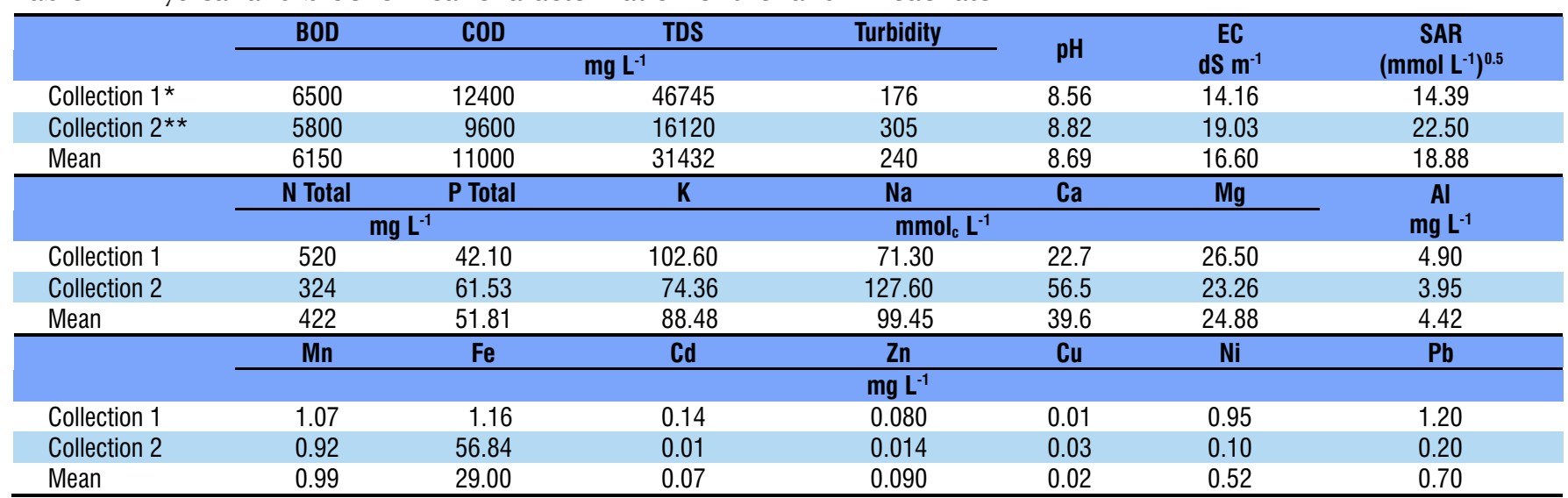

BOD - Biochemical oxygen demand; COD - Chemical oxygen demand; TDS - Total dissolved solids; EC - Electrical conductivity; SAR - Sodium adsorption ratio

* and ** samples collected on 6 and $21 / 10 / 2014$, respectively 
Drip irrigation was applied through drip tapes (16-mm diameter) with emitters spaced by $0.30 \mathrm{~m}$ and mean flow rate of $1.65 \mathrm{~L} \mathrm{~h}^{-1}$. Irrigation management was based on the product between reference evapotranspiration (ETo) and the respective crop coefficient $(\mathrm{Kc})$, adopting a daily irrigation interval. Irrigations continued up to $100 \mathrm{DAS}$, and $638.1 \mathrm{~mm}$ of water was applied in total.

Mineral fertilization was only used in the control treatment, by applying the formulation 6-24-12 before planting, using $17.5 \mathrm{~g}$ of fertilizer per hole. As top-dressing, nitrogen $(\mathrm{N})$ and potassium $(\mathrm{K})$ were applied at doses of 35 and $20 \mathrm{~kg} \mathrm{ha}^{-1}$ in the form of ammonium sulfate and potassium chloride, respectively.

At 30, 60, 90 and 120 DAS, the following variables were measured: plant height $(\mathrm{PH})$ - from the base to the bifurcation of the last leaf; stem diameter (SD) $-5 \mathrm{~cm}$ above soil surface; number of leaves (NL) - considering leaves larger than $3 \mathrm{~cm}$, healthy and photosynthetically active; and leaf area (LA) according to the methodology of Severino et al. (2004). At 90 and 120 DAS, the number of clusters, number of fruits, cluster weight and grain weight were measured.

The experimental data were subjected to analysis of variance by $\mathrm{F}$ test. The control was compared with the other treatments by orthogonal contrasts, and all treatments were compared by Tukey test. All analyses were carried out at 0.05 probability level using a statistical program (Ferreira, 2011).

\section{Results AND Discussion}

For plant height, significant contrast $(\mathrm{p}<0.05)$ was found at 30 DAS, with a $21.42 \%$ higher results between plants in the control and those receiving $80 \%$ of landfill leachate (LL). Up to this period, when 20,40 or $60 \%$ LL was used, there was no significant $(\mathrm{p}<0.05)$ variation compared with the control (Table 3).

At 60 DAS, there was no significant variation $(p>0.05)$ in $\mathrm{PH}$ between the control treatment and 20, 40 and 60\% LL, and a decrease of $27.02 \%$ in $\mathrm{PH}$ was observed $(\mathrm{p}<0.01$ ) at $80 \%$ LL. At 90 and 120 DAS, the trends of the previous times repeated, with reductions of 10.02 and $21.30 \%$ in the $\mathrm{PH}$ of plants receiving $80 \% \mathrm{LL}$.

In general, up to 60 DAS the best results of $\mathrm{PH}$ occurred in plants of the control treatment. From this period on, higher $\mathrm{PH}$ was found in plants under $60 \% \mathrm{LL}$, also higher than that in the control treatment, and the values did not differ from those in the treatments 20 and 40\% LL. In the present study, $\mathrm{PH}$ mean values at 120 DAS varied between $63.751 \mathrm{~cm}(80 \%$ LL) and $84.657 \mathrm{~cm}$ (60\% LL). Nonetheless, Soares et al. (2012), working with the same cultivar under water reuse conditions, observed mean $\mathrm{PH}$ of $68 \mathrm{~cm}$ at 100 DAS.

At 30 DAS, the SD of plants in the control treatment was up to $28.95 \%$ larger than that of plants receiving landfill leachate. At 60 DAS, the SD of plants under 40 and $60 \%$ LL did not differ $(p>0.05)$ from that in the control plants and, at 90 DAS, only the SD of plants under $40 \%$ LL did not differ (p $>0.05$ ) from that in control plants. At 120 DAS, only plants under $80 \%$ LL were significantly inferior $(\mathrm{p}<0.01)$ to those in the control treatment (11.69\%). In plants under $40 \% \mathrm{LL}$, $\mathrm{SD}$ was up to $8.22 \%$ larger compared to that of plants in the control treatment.

Thus, the results of SD under $80 \%$ LL were influenced by the osmotic effect resulting from successive applications of salts along the cycle. In theory, using up to $60 \% \mathrm{LL}$ in the castor bean crop promoted soil fertilization and led to SD results compatible with those in the control $(15.543 \mathrm{~mm})$. Nevertheless, these results were lower than those reported by Alves et al. (2015) for the same cultivar, a mean value of 21.5 $\mathrm{mm}$ in plants under water replacement levels and different populations. Also for the cultivar BRS Energia, the SD $(18 \mathrm{~mm})$ found by Silva et al. (2015) was larger than the one observed in the present study, which corroborates the reasoning based on the influence of the osmotic or ionic effect resulting from successive applications of LL.

At the beginning of the castor bean cycle, the response of the NL to mineral fertilization was faster compared with plants receiving LL, so that at 30 DAS plants in the control treatment produced up to 1.23 times more leaves in comparison to the other treatments. At 60 DAS, there was no significant effect ( $p>0.05$ ) in the contrast of NL between plants under $40 \%$ LL and those in the control treatment. At 90 DAS, the NL in control plants was up to $26 \%$ higher than that of plants under $60 \%$ LL. At 120 DAS, this trend reversed and the contrast of NL between control plants (31.937 leaves) and plants receiving LL was significantly higher $(\mathrm{p}<0.01)$ only when $80 \%$ LL was used (20.088 leaves).

In general, the NL at 120 DAS varied between 20.088 (80\% $\mathrm{LL})$ and $32.541(60 \% \mathrm{LL})$; this latter result was higher than that

Table 3. Contrasts and means for plant height, stem diameter, number of leaves and leaf area of castor bean fertilized with landfill leachate

\begin{tabular}{|c|c|c|c|c|c|c|c|c|}
\hline & \multicolumn{4}{|c|}{$\mathrm{PH}(\mathrm{cm})$} & \multicolumn{4}{|c|}{ SD (mm) } \\
\hline & 30 DAS & 60 DAS & 90 DAS & 120 DAS & 30 DAS & 60 DAS & 90 DAS & 120 DAS \\
\hline Control-C & $17.539 \mathrm{a}$ & $57.238 \mathrm{a}$ & $61.844 \mathrm{ab}$ & $81.011 \mathrm{a}$ & $7.940 \mathrm{a}$ & $12.636 \mathrm{a}$ & $12.985 \mathrm{a}$ & $15.543 \mathrm{a}$ \\
\hline C vs $20 \%$ & $15.250^{\text {ns }} a$ & $49.000^{\text {ns }} a b$ & $56.750^{\text {ns }} \mathrm{ab}$ & $74.781^{\text {ns }} \mathrm{ab}$ & $6.804^{* \star} a b$ & $10.777^{\star \star} \mathrm{a}$ & $11.050^{\star *} \mathrm{~b}$ & $14.910^{\text {ns }} \mathrm{a}$ \\
\hline C vs $40 \%$ & $16.131^{\text {ns }} \mathrm{a}$ & $51.380^{\text {ns }} a b$ & $61.074^{\text {ns }} \mathrm{ab}$ & $74.398^{\text {ns }} a b$ & $6.765^{\star *} \mathrm{ab}$ & $11.186^{\text {ns }} a$ & $12.330^{\text {ns }} a b$ & $16.821^{\text {ns }} a$ \\
\hline C vs $60 \%$ & $15.213^{\text {ns }} a$ & $50.019^{\text {ns }} a b$ & $63.704^{\text {ns }} a$ & $84.657^{\text {ns }} a$ & $6.473^{\star \star} b$ & $11.377^{\mathrm{ns}} \mathrm{a}$ & $11.923^{\star \star} \mathrm{ab}$ & $15.238^{\text {ns }} a$ \\
\hline \multirow[t]{3}{*}{ C vs $80 \%$} & $14.444^{\star *} \mathrm{~b}$ & $41.767^{\star \star} \mathrm{b}$ & $55.645^{\star \star} b$ & $63.751^{\star \star} \mathrm{b}$ & $6.157^{\star *} \mathrm{~b}$ & $7.726^{\star \star} b$ & $11.607^{\star \star} a b$ & $13.725^{\star *} \mathrm{~b}$ \\
\hline & \multicolumn{4}{|c|}{ NL(unit) } & \multicolumn{4}{|c|}{ LA $\left(\mathrm{cm}^{2}\right)$} \\
\hline & 30 DAS & 60 DAS & 90 DAS & 120 DAS & 30 DAS & 60 DAS & 90 DAS & 120 DAS \\
\hline Control-C & $7.945 \mathrm{a}$ & $13.454 \mathrm{a}$ & $15.433 \mathrm{a}$ & $31.937 a$ & $37.095 a$ & $54.394 \mathrm{a}$ & $56.658 \mathrm{a}$ & $61.265 b$ \\
\hline C vs $20 \%$ & $6.766^{\star \star} \mathrm{b}$ & $11.200^{\star \star} \mathrm{a}$ & $12.983^{\star \star} \mathrm{ab}$ & $26.587^{\text {ns }} a b$ & $32.841^{\star \star} a b$ & $39.127^{\star \star} \mathrm{bc}$ & $53.009^{\star *} b$ & $69.961^{* *} \mathrm{a}$ \\
\hline C vs $40 \%$ & $6.598^{* *} \mathrm{~b}$ & $12.005^{\mathrm{ns}} \mathrm{a}$ & $13.684^{\text {ns }} a b$ & $25.375^{\text {ns }} a b$ & $29.064^{\star *} a b$ & $52.538^{\text {ns }} a$ & $56.372^{\text {ns }} \mathrm{a}$ & $58.994^{\star *} \mathrm{C}$ \\
\hline C vs $60 \%$ & $6.811^{* \star} b$ & $11.463^{\star \star} \mathrm{a}$ & $12.248^{\star *} b$ & $32.541^{\text {ns }} a$ & $27.614^{\star *} b$ & $38.671^{* *} b c$ & $51.688^{\star *} b$ & $55.044^{* *} \mathrm{C}$ \\
\hline C vs $80 \%$ & $6.433^{\star \star} b$ & $11.248^{\star \star} \mathrm{a}$ & $13.158^{\star \star} a b$ & $20.088^{\star \star} b$ & $16.177^{\star \star} \mathrm{C}$ & $33.767^{\star \star} \mathrm{C}$ & $40.805^{\star \star} \mathrm{C}$ & $54.313^{\star \star} \mathrm{C}$ \\
\hline
\end{tabular}

Control - Irrigation with public-supply water + mineral fertilization; 20, 40, 60 and $80 \%$ refer to the percentages of landfill leachate; ${ }^{*, * *}$ and ${ }^{n s} \mathrm{Contrast}$ significant at 0.05 and 0.01 probability levels and not significant, respectively; Lowercase letters compare treatment means within the same period of the cycle 
Table 4. Contrasts and means for number of clusters (NC), number of fruits (NF), cluster weight (CW) and grain weight (GW) per plant, in castor bean fertilized with landfill leachate

\begin{tabular}{|c|c|c|c|c|c|c|c|c|}
\hline & \multicolumn{2}{|c|}{ NC (unt) } & \multicolumn{2}{|c|}{ NF (unt) } & \multicolumn{2}{|c|}{ CW (g) } & \multicolumn{2}{|c|}{ GW (g) } \\
\hline & $1^{\text {st }}$ Harv. & $2^{\text {nd }}$ Harv. & $1^{\text {st }}$ Harv. & $2^{\text {nd }}$ Harv. & $1^{\text {st }}$ Harv. & $2^{\text {nd }}$ Harv. & $1^{\text {st }}$ Harv. & $2^{\text {nd }}$ Harv. \\
\hline Control-C & $4.567 \mathrm{a}$ & $3.500 \mathrm{a}$ & 40.412 a & 30.977 a & $35.010 \mathrm{a}$ & $25.627 \mathrm{a}$ & $481.11 \mathrm{ab}$ & 366.37 b \\
\hline C vs $20 \%$ & $4.232^{\mathrm{ns}} \mathrm{a}$ & $3.217^{\text {ns }} a$ & $39.837^{\text {ns }} a$ & $23.175^{\star \star} b$ & $32.157^{\text {ns }} \mathrm{ab}$ & $24.357^{\mathrm{ns}} \mathrm{a}$ & $559.71^{\star \star} \mathrm{a}$ & $424.17^{\star \star} a b$ \\
\hline C vs $40 \%$ & $3.962^{\text {ns }} \mathrm{ab}$ & $3.012^{\text {ns }} \mathrm{a}$ & $37.575^{\text {ns }} \mathrm{a}$ & $15.167^{\star *} \mathrm{C}$ & $28.452^{\star *} a b$ & $22.710^{\text {ns }} \mathrm{a}$ & $486.96^{\text {ns }} \mathrm{ab}$ & $460.11^{\star \star} \mathrm{a}$ \\
\hline C vs $60 \%$ & $3.562^{\star \star} a b$ & $2.850^{* \star} \mathrm{a}$ & $28.200^{\star *} a b$ & $7.212^{\star \star} d$ & $25.632^{\star *} b$ & $21.340^{\text {ns }} \mathrm{a}$ & $397.90^{\star \star} \mathrm{b}$ & $484.14^{\star \star} \mathrm{a}$ \\
\hline C vs $80 \%$ & $2.600^{\star \star} \mathrm{b}$ & $1.475^{\star \star} \mathrm{b}$ & $22.987^{\star \star} \mathrm{b}$ & $5.662^{\star \star} \mathrm{d}$ & $24.787^{\star \star} \mathrm{b}$ & $20.805^{\text {ns }} a$ & $403.11^{\star \star} \mathrm{b}$ & $265.79^{\star \star} \mathrm{C}$ \\
\hline
\end{tabular}

Control - Irrigation with public-supply water + mineral fertilization; 20, 40, 60 and $80 \%$ refer to the landfill leachate percentages; ${ }^{*},{ }^{* \star}$ and ${ }^{n s} \mathrm{Contrast}$ significant at 0.05 and 0.01 probability levels and not significant, respectively; Lowercase letters compare treatment means within the same variable; NC - Number of clusters; NF - Number of fruits; CW - Cluster weight; GW - Grain weight; Harv. - Harvest

found by Alves et al. (2011), also for the cultivar BRS Energia, under drip irrigation. It is worth highlighting that, from 20 to $60 \% \mathrm{LL}$, there was no significant variation $(\mathrm{p}>0.01)$ in the NL compared with the control.

Initially, LA also responded faster to mineral fertilization, i.e., at $30 \mathrm{DAS}$, the values were up to 2.29 times higher than those in plants receiving landfill leachate. As in the above-discussed biometric variables, the results for the contrast of LA between plants under $40 \%$ LL and those in the control did not differ ( $\mathrm{p}$ $>0.05$ ), as also occurred at 60 and 90 DAS. These results may be related to the successive nutritional supply from the LL, as also observed in plants under $20 \% \mathrm{LL}$, which managed to surpass by $14.19 \%$ those in the control treatment regarding LA at 120 DAS.

In short, at the end of the biometric analyses (120 DAS), the higher LA in plants under 20\% LL, also higher than that in control plants, is probably attributed to the accumulation of nutrients due to LL application, but also to the osmotic condition that was created by this specific supply percentage, since there is a direct correlation between this variable and gas exchanges (Ferraz et al., 2012) and photosynthetic aspects (Reis et al., 2013).

The number of clusters in plants under 20 and $40 \%$ LL, both in the first and second harvests, were not different $(\mathrm{p}>0.05)$ from those found in plants under mineral fertilization, whose results were 75.65 and $137.28 \%$ superior to those of plants under $80 \% \mathrm{LL}$ in the first and second harvests, respectively (Table 4 ).

Although the NC produced in the second harvest was lower in all treatments based on LL, compared with the control, the reduction percentages were lower than at the first harvest except in $80 \%$ LL. Nóbrega et al. (2001) comment that the number of racemes/clusters plant ${ }^{-1}$ in castor bean is considered as low when lower than 3 , intermediate when between 3 and 6 and high when higher than 7 . Thus, at the first harvest, plants showed intermediate production, except those under $80 \%$ LL. At the second harvest, plants under 60 and $80 \%$ showed low production and intermediate production occurred in the other cases.

At the first harvest, there was no significant difference ( $p>0.05$ ) in the number of fruits between plants under 20 and $40 \% \mathrm{LL}$ and those in the control treatment, and the control treatment showed $75.80 \%$ superiority over $80 \%$ LL. At the second harvest, the contrast between the control and treatments based on LL was significant $(p<0.01)$, which may be attributed to the interruption of irrigation and the supply of nutrients, or to the need for complementary fertilization.

In castor bean plants (cv. BRS Energia) irrigated with $4.4 \mathrm{dS} \mathrm{m}^{-1}$ water, Nobre et al. (2012) estimated 39.15 fruits per cluster, i.e., a value higher than that found in the present study in plants under 60\% LL (28.20 fruits) and 80\% LL (22.98 fruits) at the first harvest, while only under mineral fertilization the NF was higher than 30 fruits per plant, at the second harvest.

Except for plants receiving 20\% LL, the cluster weights in plants of the other treatments based on LL (40,60 and 80\%) were $18.73,26.78$ and $29.20 \%$ lower than those of control plants, respectively, at the first harvest. At the second harvest, there was no difference between treatments $(p>0.05)$ or significant contrast $(\mathrm{p}>0.05)$ compared with the control.

For grain weight, the results of plants under 20 and $40 \%$ LL were 1.16 and 1.01 times higher than those of plants in the control treatment. At the first harvest, $559.71 \mathrm{~g}$ were produced by plants under $20 \% \mathrm{LL}$ and, at the second harvest, plants under $60 \%$ LL showed the highest grain weight among the treatments tested (484.14 g). However, considering the sum of the means relative to the first and second harvests, plants under 20\% LL stood out from the others, including those in the control treatment.

In general, seed production of $484.4 \mathrm{~g}$ in plants under $60 \% \mathrm{LL}$ at the second harvest is expressive compared with the results found by Silva et al. (2008) for the cv. BRS Energia. These authors observed that, at ECw above $4.7 \mathrm{dS} \mathrm{m}^{-1}$, plants did not produce fruits. In summary, production results closest to that of control plants were found in plants under $20 \%$ LL.

\section{Conclusions}

1. The biometric variables of plants that received landfill leachate were compatible with those of the control, especially plants under $20 \%$ landfill leachate.

2. In plants under up to $40 \%$ landfill leachate, the number of clusters, cluster weight and grain weight, as well as the number of fruits (at the first harvest) were equivalent or superior to those obtained in the control treatment.

3. The biometric and production results obtained by plants under $80 \%$ landfill leachate were always lower than those in the control treatment.

\section{Literature Cited}

Alves, G. da S.; Tartaglia, F. de L.; Beltrão, N. E. de M.; Sampaio, L. R.; Freire, M. A. de O. Densidade populacional e seu efeito na produtividade da mamoneira BRS Energia sob cultivo irrigado. Revista Ciência Agronômica, v.46, p.546-554, 2015. http://dx.doi. org/10.5935/1806-6690.20150037

Alves, W. W. A.; Azevedo, C. A. V. de; Dantas Neto, J.; Lima, V. L. A. de. Área foliar do algodoeiro irrigado com água residuária adubado com nitrogênio e fósforo. Revista Verde de Agroecologia e Desenvolvimento Sustentável, v.4, p.41-46, 2011. 
Avramidou, P.; Evangelou, A.; Komilis, D. Use of municipal solid waste compost as a growth media for an energy plant (rapessed). Journal of Evironmental Management, v.121, p.152-159, 2013. https://doi.org/10.1016/j.jenvman.2013.02.046

Brito, K. Q. D.; Souza, F. G.; Dantas Júnior, G. J.; Brito, K. S. A. Efeito da salinidade na germinação e desenvolvimento inicial da mamona 'BRS Energia'. Revista Verde de Agroecologia e Desenvolvimento Sustentável, v.10, p.17-20, 2015. https://doi.org/10.18378/rvads. v10i4.3344

Coelho, D. da C. L.; Batista, R. O.; Oliveira, A. de F. M.; Silva, K. B. da. Chemical changes in Argisol irrigated with landfill leachate and water supply. Revista Brasileira de Engenharia Agrícola e Ambiental, v.19, p.598-604, 2015. https://doi.org/10.1590/18071929/agriambi.v19n6p598-604

Crusciol, C. A. C.; Nascimento, M. S. do; Fernandes, A. M.; Zanotto, M. D. Extração e exportação de nutrientes pelo híbrido de mamona Savana: I - Macronutrientes. Semina: Ciências Agrárias, v.33, p.2619-2636, 2012. https://doi.org/10.5433/16790359.2012v33Supl1p2616

EMBRAPA - Empresa Brasileira de Pesquisa Agropecuária. Centro Nacional de Pesquisa de Solos. Manual de métodos de análise de solo. 2.ed. Brasília: EMBRAPA, 1997. 212p.

Ferraz, R. L. de S.; Melo, A. S. de; Suassuna, J. F.; Brito, M. E. B. de; Fernandes, P. D.; Nunes Júnior, E. da S. Trocas gasosas e eficiência fotossintética em ecótipos de feijoeiro cultivados no semiárido. Pesquisa Agropecuária Tropical, v.42, p.181-188, 2012. https:// doi.org/10.1590/S1983-40632012000200010

Ferreira, D. F. Sisvar: A computer statistical analysis system. Ciência e Agrotecnologia, v.35, p.1039-1042, 2011. https://doi.org/10.1590/ S1413-70542011000600001

Nobre, R. G.; Lima, G. S. de; Gheyi, H. R.; Medeiros, E. P. de; Soares, L. A. dos A.; Alves, A. N. Teor de óleo e produtividade da mamoneira de acordo com a adubação nitrogenada e irrigação com água salina. Pesquisa Agropecuária Brasileira, v.47, p.991-999, 2012. https://doi.org/10.1590/S0100-204X2012000700016

Nóbrega, M. B. de M.; Andrade, F. P.; Santos, J. W.; Leite, E. J. Germoplasma. In: Azevedo, D. M. P.; Lima, E. F. (eds.) O agronegócio da mamona no Brasil. Brasília: EMBRAPA, 2001. Cap.11, p.257-280.

Nunes Júnior, F. H.; Gondim, F. A.; Pereira, M. de S.; Braga, B. B.; Pontes Filho, R. A.; Barbosa, F. E. L. Sanitary landfill leachate as a source of nutrients on the initial growth of sunflower plants. Revista Brasileira de Engenharia Agrícola e Ambiental, v.20, p.746-750, 2016. https:// doi.org/10.1590/1807-1929/agriambi.v20n8p746-750
Reis, L. S.; Azevedo, C. A. V. de; Albuquerque, A. W.; Silva Júnior, J. F. Índice de área foliar e produtividade do tomate sob condições de ambiente protegido. Revista Brasileira de Engenharia Agrícola e Ambiental, v.17, p.386-391, 2013. https://doi.org/10.1590/S141543662013000400005

Ribeiro, M. C. de F.; Rocha, F. A.; Santos, A. C. dos; Silva, J. O. da; Peixoto, M. de F. S. P.; Paz, V. P. da S. Crescimento e produtividade da mamoneira irrigada com diferentes diluições de esgoto doméstico tratado. Revista Brasileira de Engenharia Agrícola e Ambiental, v.16, p.639-646, 2012. https://doi.org/10.1590/S141543662012000600008

Rice, E. W.; Baird, R. B.; Eaton, A. D.; Clesceri, A. D. (ed.). Standard methods for the examination of water and wastewater. 22.ed. Washington: American Public Health Association, 2012. 1496p. Severino, L. S.; Cardoso, G. D.; Vale, L. S. do; Santos, J. W. dos. Método para determinação da área foliar da mamoneira. Revista Brasileira de Oleaginosas e Fibrosas, v.8, p.753-762, 2004.

Silva, E. C. da; Nogueira, R. J. M. C.; Araújo, F. P. de; Melo, N. F. de; Azevedo Neto, A. D. de. Physiological responses to salt stress in young umbu plants. Environmental and Experimental Botany, v.63, p.147-157, 2008. https://doi.org/10.1016/j. envexpbot.2007.11.010

Silva, S. M. S. e; Gheyi, H. R.; Beltrão, N. E. de M.; Santos, J. W. dos; Soares, F. A. L. Dotações hídricas em densidades de plantas na cultura da mamoneira cv. BRS Energia. Revista Brasileira de Ciências Agrárias, v.4, p.338-348, 2015. https://doi.org/10.5039/ agraria.v4i3a17

Simões, K. da S.; Peixoto, M. de F. da S. P.; Almeida, A. T.; Ledo, C. A. da S.; Peixoto, C. P.; Pereira, F. A. de C. Água residuária de esgoto doméstico tratado na atividade microbiana do solo e crescimento da mamoneira. Revista Brasileira de Engenharia Agrícola e Ambiental v.17, p.518-523, 2013. https://doi.org/10.1590/S141543662013000500008

Soares, L. A. dos A.; Nobre, R. G.; Gheyi, H. R.; Lima, G. S. de; Silva, A. O. da; Soares, S. da S. Componentes de crescimento da mamoneira cultivada com águas salinas e doses de nitrogênio. Irriga, v.1, p.4054, 2012. https://doi.org/10.15809/irriga.2012v1n01p40

Vera-Romero, I.; Estrada-Jaramillo, M.; Martínez-Reyes, J.; OrtizSoriano, A. Potencial de generación de biogás y energía eléctrica. Parte II: Resíduos sólidos urbanos. Ingeniería, Investigación y Tecnología, v.16, p.471-478, 2015. https://doi.org/10.1016/j. riit.2015.05.012 